\title{
Role of Ayurved in the Management of Wound Dehiscence - A Case Report
}

\author{
Case Report
}

\section{Kiran Pundlikrao Mendhekar1*, Sanjay C Babar², Ashwin A Shete ${ }^{3}$}

1. Assistant Professor, 2. Professor and HOD, Department of Shalya Tantra,

3. Assistant Professor, Department of Rasashastra and Bhaishajya Kalpana

Dr. D. Y. Patil College of Ayurved and Research Centre, Pimpri. Pune.

Dr. D. Y. Patil Vidyapeeth, Pune (Deemed to be).

\begin{abstract}
Wound dehiscence is the common problem which is faced by most of the surgeons in case of obese people. As we know, in case of post-operative wound management, avascularity and excessive adipose tissue lysis can lead to fluid collection which leads to gapping of sutured wound. This may also cause Dushta vrana i.e. secondary infection to the wound. Wound dehiscence in surgical field leads to most fatal outcome which can lead to cause local as well as systemic sepsis in the patient. Present case report reveals a treatment modality which involves multidisciplinary team approach such as management of wound as well as obesity by using Ayurvedic perspective. Whereas modern technique of resuturing the gapped wound exposes patient to another surgical procedure which is expensive and increases the hospital stay. The local and oral drugs formulations were proven effective in reducing excessive wound discharge as well as they stimulate the wound healing mechanism when administered in both local and systemic ways. The cost and benefit ratio was found high as there is no re-exposure to the surgical procedure and patient will get benefitted with non-invasive technique along with minimal expenses and hospital stay.
\end{abstract}

Key Words: Wound dehiscence, Obesity, Kshar tail application, Chandraprabhavati, Triphala gugggulu, Wound healing without resuturing.

\section{Introduction}

Wound dehiscence or post-operative gapping of the wound can be considered as Chinna vrana (Incised wound) mentioned by Sushrutacharya, is a commonest problem in the obese patients in the field surgery. (1)(2)

Charakachrya also mentioned that obese people are prone to develop fatal conditions and are difficult to treat.(2) Complications of surgery in such patients includes gapping of the wound due to dhatushaithilya due to vitiated dosha (2)which is similar to excessive tissue adepolysis mentioned as per the modern science can be considered due to inherent anatomical feature, vascular insufficiency, cellular and composition modification, alteration in immune mediators and nutritional deficiencies. Components of intravascular fluid may leak into surrounding tissue because of increased hydrostatic pressure, inciting an inflammatory response. Poor oxygenation and tissue distraction can lead to impaired wound healing in the post-operative period. (3)(4)

In modern science, Surgical attempt can be made to correct wound dehiscence with debridement and resuturing of the post-operative wound with proper wound

\section{* Corresponding Author:}

\section{Kiran Pundlikrao Mendhekar}

Assistant Professor, Department of Shalyatantra,

Dr. D. Y. Patil college of Ayurved and Research Centre, Pimpri. Pune. Dr. D.Y Patil Vidyapeeth. Pune (Deemed to be) Maharashtra, India.

Email Id: doctor.kiran.mendhekar@gmail.com assessment. But that again expose the patient to the another surgical procedure and prolongs the hospital stay.

Such cases can be treated with Ayurvedic treatment modalities which includes internal medication i.e. abhyantar chikitsa with Chandraprabhavati and triphala guggulu along with local application of Kshar tail. (5)(6)(7)(8) This will promote rapid healing of wound dehiscence without any surgical intervention.

\section{A Case report}

A 33 years old male patient presented with Umbilical hernia with omentum as a content in the hernia sac and hernioplasty done. Patient was known case of Hypertension on tab Cilacart $12.5 \mathrm{mg}$ od. On admission weight $93 \mathrm{~kg}$.

Clinical findings of post operative wound were as follows: Local /examination: Pain at operated site with induration and blood stained serous discharge. No any other systemic complains were noted.

Laboratory profile of the patient was found to have $\mathrm{CBC}=$ 10.9/5500/3.98; Sr. Creatinine = 0.9; BSL $(\mathrm{R})=98$; $\mathrm{HIV}=$ Non reactive; $\mathrm{HbsAg}=$ negative; $\mathrm{CXR}(\mathrm{PA}$ view $)=$ Within normal limits; B.T. And C. T. = Within normal limits; Ultrasonography of Abdomen = Reducible umbilical hernia.

\section{Treatment schedule}

After surgery, routine post operative care has been continued along with administration of Antibiotics and Analgesics. Abdominal belt has been applied to avoid 
Kiran Pundlikrao Mendhekar et.al., Role of Ayurved in the management of Wound Dehiscence. - A Case Report

tension over the post-operative wound. Daily dressing has been done with the Ayurvedic herbomineral formulations.

\section{Materials and methods}

\section{Materials}

A) Bahya chikitsa (External medication)

1. Normal saline

2. Kshar tail - Each 10ml Sidhha Tail.

Contents = Manjishtha (Rubia cordifolia L) -0.62gm, Haridra (Curcuma longa L)-156.36gm, Mulakkshar (Raphanus sativus L.), Yavakshar(Hordeum Vulgare L), Svarjikshar (Sodium Carbonate), Lavanpanchak=Sauvarchala (Anaqua Sodichloridium, Unqua Sodii Chloredum, Black salt) + Saindhava( Sodii Chloridum, Sodium chloride, Rock salt) + Bid (Amonium Chloride) + Audbhida(Pot Nitre) + Samudra (Sodii muras, Sodium chloride, Sodii muri) (10); Hingu (Ferula narthex L), Shobhanjan (Moringa oliefera Linn), Sunthi (Zinziber officinale ROSC), Vacha (Acorus calamus L), Devdar (Cedrus deodara L), Kustha (Sassurea lappa L), Shatpushpa (Anethum sowa L), Rasanjan (Root Extract from Barberis Barberis aristata L decoction processed with milk), Pimpalimula (Piper longum radix), Musta (Cyprus rotundus L) 156.36gm; Kadulimba (Azadiracta indica A.) juice, Matulung (Citrus medica L.) juice, Madhusukta (fermented liquid using the honey)- 40ml each + Base = Sarshap (Brassica compestris L) tail(oil)-10ml (Manufactured by Bidyanath Pharmacy)(5)(6)(11)

B) Abhyantar chikitsa (Internal medication)Chandraprabh vati 4 tablets TDS, Triphala guggulu 4 tablets TDS with water for 14 days. (Manufactured by Sudhatatva Pharmacy of Dr.D.Y.Patil College of Ayurved and Research centre, Pimpri. Pune-81.(7)(8)

\section{Method of application of Kshar tail:}

Wound cleaning and dressing done with normal saline followed by kshar tail application with sterile gauze under all aseptic precautions.

\section{Methodology}

1. Wound dehiscence was observed on day 2 after operative procedure associated with mild fluid collection. Sutures over the affected part were removed and wound opened. Cleaning done with normal saline and dressing done with kshar tail. Daily dressing done in the same manner. Fig 1.2

2. Assessment of the wound done after every 3 days of dressing.

3. Fluid collection was reduced in successive dressings as chandraprabhavati and triphala guggulu continued systemically along with kshar tail application. Fig 1.4

4. As per the assessment of the wound, quantity of kshar tail used for local application was reduced till post-operative day 10 as wound size was reduced .

5. Edges of post-operative wound then kept close together followed by putting a drop of kshar tail on it for next 2 days

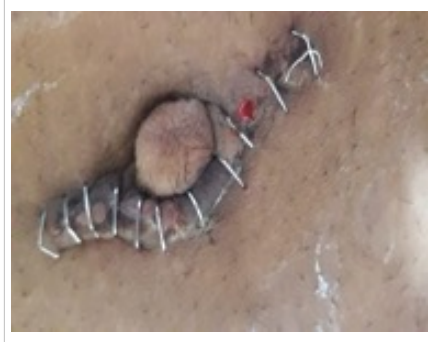

Fig 1.1 Wound dehiscence Post-op-Day 1

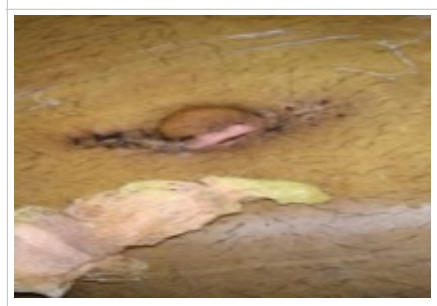

Fig 1.3 Wound dehiscence Post-op-Day 2 after suture removal

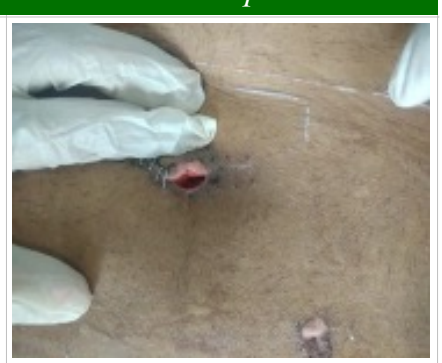

Fig 1.2 Post-Op-Day 2 gapping of the wound after surgery

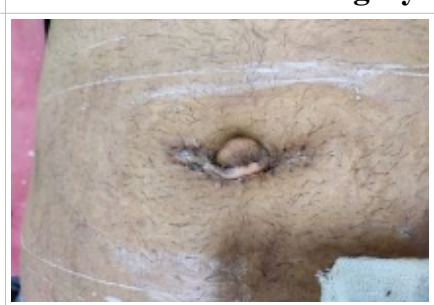

Fig 1.4 Wound dehiscence Post-Op-Day 8

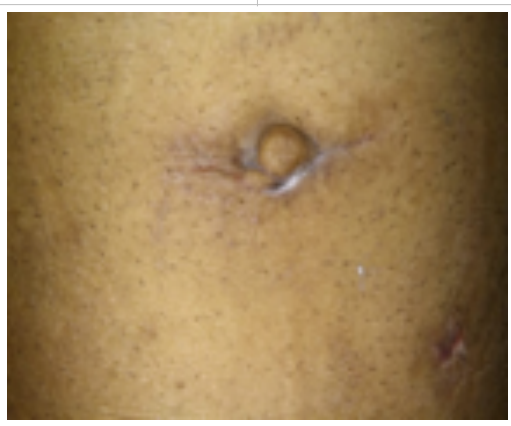

Fig 1.5 Completely healed wound on Post Operative Day 12

\section{Chronology of clinical observation}

1. On Post-Operative Day 4, blood stained serous fluid collection was reduced significantly and wound was found collapsing from the base.

2. Post-Operative Day 7, fluid collection was found negligible followed by healing of the wound dehiscence.

3. Post-Operative Day 10, a small cavity in the subcutaneous plane and skin was found and edges were kept close together for further wound healing by putting a drop of kshar tail on it.

4. Wound was healed completely on Post-Operative Day 12.

\section{Discussion}

All contents of Chandraprabha vati and Triphala guggulu found to have Vrana Shodhan (antimicrobial) as well as Vrana Lekhan \& Rukshan property (wound cleaning and drying action).Along with this it has wound healing action (Ropan) also.(7) (8)

They also helped to reduce obesity by reducing excessive water content (diuretic action). So, it also reduces excessive tissue discharge from the wound dehiscence. 
Chandraprabha vati help to restore normal wound healing by stimulating correct dhatupariposhan (tissue metabolism) in the obese person as well as in the wound(7).

Suvarna makshik and Loha stimulates vascularization in the wound.(7)

Shilajatu has medoghna (adepolysis)and kledaghna (drying of abnormal wound discharge i.e. tissue liquefaction and distraction) action on the wound. It has rasayana (rejuvenating) effect by enhancing wound healing property.(7)

Triphala Guggulu has shothaghna (antiinflammatory), and (antilipidemic) medoghna and ropan (wound healing )action on the post-operative wound.(8)(9)

Kshar tail has shodhan and ropan action. It also helps to reduce the post- operative pain.(6) (8)(9)(11)

\section{Conclusion}

- Wound dehiscence can be rapidly healed with Ayurved perspective.

- It prevents re-exposure of the patient towards surgical debridement and resuturing which ultimately avoids morbidity in the case of wound dehiscence.

- Needs minimum hospital stay.

- It is cost effective.

\section{Further scope of study -}

- This is a single case study on post-operative wound management without resuturing of the wound. So various types of post-operative wounds or incised wounds are need to be assessed to ensure the potency of Ayurvedic formulations in Sandhan karma ( tissue repair and reconstruction) from the perspective of plastic and reconstructive surgery mentioned in the modern science.

- This will give better opportunity for healing of shastrakrit vrana (post-operative wound) without any surgical intervention with minimal cost expense.

\section{References}

1. Yadavaji Trikamji et al. Sushrut Samhita Chikitsa sthan of Acharya Sushruta, 1sted, Varanasi, Choukhamba Sanskrit Sansthan,1997

2. Shastri Kashinath, Vidyotini Charaka Samhita Sutrasthan Adhyay21 of Agnivesha, 2nd ed, Varanasi,. Chaukhambha Bharati Sansthan, 2005,408p

3. Neha Lamba, The Concept of Medorogan \& Its Management Through Ayurveda 160 IAMJ:5; Issue 1; January- 2017

4. Yvonne N. Dierpont et al. A current review on obesity and surgical wound healing ISRN Obes. 2014 feb20;638936

5. P.V.Sharma Dravyaguna Vidnyan-Vol 1-2(series3) Choukhamba surbharati publications

6. Ashish Parik, Shalyavidnyan, Part-I,Vol-1,1 sted, Varanasi, Choukhamba surbharati publications, 2018,101-109p

7. Gangadharshastri Gune, Ayurvediya Aushadhigundharma Shastra,2nded, Pune,Viadyak granth bhandar,2008,311p

8. Ambikadatta, Bhaishajya Ratnavali of Shree Govind Das, 2nded, Varanasi, Choukhamba Prakashan 2015,849p

9. Rakhi Mehra et al-A Clinical study on effect of ksar vasti and triphala guggulu in raktarsha. AYU 2011Apr-June32(2),192-195p.

10. Shweta parwe, Effect of Panchlavan churna with goghruta in malavasthambha, WJPR 7(16), August 2018,757-766p

11. Sharangdhar, Sharangdhar Samhita, 9/174-177, Madhyam khand,Varanasi, Chukhamba surbharati Prakashan 2015,160p. 